\title{
Diversity of Zooplankton in Seagrass Ecosystem of Mandapam Coast in Gulf of Mannar
}

\author{
S. Deepika ${ }^{1 *}$, A. Srinivasan ${ }^{1}$, P. Padmavathy ${ }^{1}$ and P. Jawahar ${ }^{2}$ \\ ${ }^{1}$ Department of Aquatic Environment Management \\ ${ }^{2}$ Department of Fisheries Biology and Resource Management, Fisheries College and \\ Research Institute, Tamil Nadu Dr. J. Jayalalithaa Fisheries University, Thoothukudi-628 \\ 008. Tamil Nadu, India \\ *Corresponding author
}

\section{A B S T R A C T}

\begin{tabular}{|l|}
\hline K e y w o r d s \\
Seagrass ecosystem, \\
$\begin{array}{l}\text { Zooplankton, } \\
\text { Physico chemical } \\
\text { parameters, Species } \\
\text { composition, } \\
\text { Species diversity } \\
\text { index }\end{array}$ \\
\hline Article Info \\
\hline $\begin{array}{l}\text { Accepted: } \\
\text { 15 June } 2019 \\
\text { Available Online: } \\
\text { 10 July } 2019\end{array}$ \\
\hline
\end{tabular}

\section{Introduction}

Among the marine ecosystems, coastal areas of the seas are more fertile and productive regions than the offshore regions of the sea. Worldwide approximately half of the population live in coastal zones and about a billion people rely on the coastal environment for fish as their main source of protein. Coastal environment is very dynamic with much cyclic and random process owing to a
The present investigation was carried out to assess the distribution of zooplankton in seagrass ecosystem in comparison with that of the coastal waters without seagrasses in Gulf of Mannar. Water and plankton samples were collected from the seagrass ecosystem (Station 1) and the control station without seagrasses (station 2) from September 2016 to May 2017. The physico chemical parameters were analysed and the mean values of surface water temperature, salinity, $\mathrm{pH}$, dissolved oxygen, nitrite, nitrate, phosphate, silicate, gross primary productivity and chlorophyll-a were $27.72^{0} \mathrm{C}, 34.17 \mathrm{ppt}, 7.99,3.85$ ml.1 $1^{-1}, 0.25 \mu \mathrm{M}, 0.01 \mu \mathrm{M}, 0.63 \mu \mathrm{M}, 1.03 \mu \mathrm{M}, 0.22 \mathrm{mg} . \mathrm{C} . \mathrm{m}^{-3} . \mathrm{h}^{-1}$ and $0.24 \mathrm{mg} . \mathrm{m}^{-3}$ respectively. Totally, 59 species of zooplankton were recorded from each of the two stations with the maximum density of 667400 and 935300 nos. $\mathrm{m}^{-3}$ in station 1 and 2 respectively. The higher density of zooplankton was observed during the summer months. The species richness and diversity indices showed the maximum values of 7.13 and 1.58 bits.ind ${ }^{-1}$ respectively in seagrass ecosystem which indicates that the diversity of plankton is more in seagrass ecosystem as that of the coastal waters without seagrasses.

variety of resources and habitats and the coastal ecosystems are the most productive ecosystems on earth. Planktons are one of the important component of any aquatic ecosystem as these organisms forms the base of the food chain. The distribution and growth of plankton depend on the availability of the inorganic nutrients and the physico chemical characteristics of the coastal waters. Zooplankton are small heterotrophic animals, plays a key role in the coastal as well as 
oceanic food web. They form the intermediate link between phytoplankton and fishes of the higher trophic levels and are playing the important link in the transfer of energy from primary producers to the organisms of the higher trophic levels. Zooplankton also includes the early life history stages of commercially important fin fishes (ichthyoplankton) and shell fishes. Zooplankton are being used as indicators of the overall health of the ecosystem, since they responds quickly to aquatic environmental changes. Temperature, salinity, and food supply are some of the important factors that are known to cause spatial changes in zooplankton populations (Fernandes and Ramaiah, 2009).

GoM located between Rameswaram and Kanyakumari has a chain of 21 Islands (area of each Island 0.95 to 130 ha.) along the 140 $\mathrm{km}$ stretch between Tuticorin and Rameswaram at $08^{\circ} 55^{\prime}-09^{\circ} 15^{\prime} \mathrm{N}$ lat. and 78 $0^{\prime}-7^{\circ} 16^{\prime} \mathrm{E}$ long (Gopakumar et al., 2009). The GoM is unique for its heterogenous biological resources and commonly known as the 'Paradise of Marine Biologists', which is a legally protected Marine Biosphere Reserve (Jyothibabu et al., 2013). They have fringing and patchy coral reefs, seaweeds, seagrasses and mangrove rising from shallow areas of the sea shore. They are biologically diverse, ecologically productive and economically valuable ecosystems which import and export considerable amount of nutrients and organic matter between the terrestrial and marine ecosystems. Presence of multiple habitats like seagrass beds, coral reefs and mangroves not only supports a rich variety of fauna but also provides natural protection from storms and waves.

\section{Materials and Methods}

The present investigation was carried out to study the zooplankton diversity in seagrass ecosystem at Chinnapaalam (Station 1, lat
$9^{0} 15^{\prime} 55^{\prime \prime} \mathrm{N}$; long $\left.79^{0} 12^{\prime} 23^{\prime \prime} \mathrm{E}\right)$ in comparison with the reference site without seagrasses at Kundhukal (Station 2, lat $9^{0} 15^{\prime} 13 " \mathrm{~N}$; long $79^{0} 13^{\prime} 8^{\prime \prime E}$ ) (Fig. 1) which is situated $2 \mathrm{~km}$ away from station 1 . The surface water sample and plankton samples were collected once in a month from the two stations (1 and 2) from September 2016 to May 2017 to analyse the physico chemical parameters of the water and to assess the diversity and biomass of phytoplankton. The water samples were collected early in the morning at 7.00 a.m. to 9.00 a.m. in both the stations. Surface water temperature was measured using standard mercury filled centigrade thermometer with an accuracy of $0.1^{\circ} \mathrm{C}$ in the sample collection site itself. The surface water samples were collected in a pre-cleaned polypropylene bottle in all the stations and transported to the laboratory for further analysis. The physico chemical parameters viz., salinity, $\mathrm{pH}$, dissolved oxygen, nutrients (nitrite, nitrate, phosphate and silicate), primary productivity and chlorophyll-a were analysed for all the water samples by following the standard procedure of Strickland and Parsons (1972).

Plankton samples were collected from the surface water by filtering 5001 of seawater using hand plankton net (bolting silk no.30). The collected plankton samples were preserved in plastic bottle with $5 \%$ formalin in the site itself for further analysis at the laboratory. Plankton samples were analysed for their species composition and plankton density using Nikon Inverted Microscope (Eclipse TS 100). Zooplankton was identified using the keys of the standard publications of Kasturirangan (1963) and Santhanam and Srinivasan (1994). For the quantitative estimation of phytoplankton, from the plankton concentrate $1 \mathrm{ml}$ of sub sample was taken in a Sedgewick-Rafter counting cell which was subsequently placed in microscope provided with a stage for counting. The density of zooplankton was expressed as 
numbers per $\mathrm{m}^{3}$. For each sample, two counting were made and the average was recorded. The species richness (D) of plankton samples was determined following Gleason (1922) and species diversity was calculated as per Shannon and Wiener (1949).

\section{Results and Discussion}

\section{Physico chemical parameters}

The results of physico chemical parameters such as surface water temperature, salinity, $\mathrm{pH}$, dissolved oxygen, nutrients (nitrite, nitrate, phosphate and silicate), gross primary productivity and chlorophyll-a of station 1 and 2 were depicted in Table 1 and 2.

\section{Zooplankton}

In the present investigation, a total of 65 species of zooplankton were recorded from the two stations. At station 1, a total of 59 species of zooplankton were found to be distributed. The percentage composition and number of species were tintinnids (11.87\% and 7 numbers), foraminifers (1.69\% and 1 number), copepods (47.46\% and 28 numbers), cladocerans $(3.39 \%$ and 2 numbers $)$, chaetognaths $(1.69 \%$ and 1 number $)$, chordates (1.69\% and 1 number), decapods (1.69\% and 1 number), molluscs (1.69\% and 1 number) and meroplanktonic forms (28.83\% and 17 numbers). The number of species distributed during different months was ranged from 18 to 40 , while the minimum numbers was during the month of September 2016 and the maximum numbers during April 2017. At station 2, a total of 59 species of zooplankton were recorded. The percentage composition and number of species were tintinnids $(8.47 \%$ and 5 numbers $)$, foraminifers $(5.08 \%$ and 3 numbers $)$, copepods (44.07\% and 26 numbers), cladocerans $(3.39 \%$ and 2 numbers $)$, chaetognaths $(1.69 \%$ and 1 number $)$, chordates (1.69\% and 1 number), decapods (1.69\% and 1 number), molluscs (1.69\% and 1 number) and meroplanktonic forms (32.20\% and 19 numbers). The number of species distributed during different months was ranged from 19 to 36 , while the minimum numbers was during the month of October 2016 and the maximum numbers during April 2017. Copepods were recorded as the dominant zooplankton species from the present study.

Among the zooplankton species recorded, the species such as Favella phillippinensis, Acrocalanus gracilis, Paracalanus parvus, Corycaeus danae, Oithona brevicornis, Euterpina acutifrons, Longipedia weberi, Sagitta sp., Bivalve veliger, Gastropod veliger, copepod nauplius and Lucifer zoea were found to be distributed commonly during all months in both the stations.

The overall zooplankton density at station 1 ranged between 126900 and 667400 nos. $\mathrm{m}^{-3}$ (Figure 2). The minimum and maximum densities were during the months of September 2016 and May 2017 respectively. The maximum density during May 2017 was contributed mainly by crustacean nauplius (33.10\%) followed by copepod nauplius (21.13\%), Oithona brevicornis (19.01\%) and Acrocalanus gracilis ( $8.45 \%)$. In station 2, the overall density of zooplankton ranged from 89300 to 935300 nos. $\mathrm{m}^{-3}$ (Figure 2). The minimum and maximum densities were occurred during the months of October 2016 and May 2017 respectively.

The maximum density during May 2017 was contributed mainly by copepod nauplius (21.11\%) followed by crustacean nauplius (14.07\%), gastropod veliger $(9.05 \%)$, Oithona brevicornis (8.54\%), Acrocalanus gracilis (6.53\%), Acartia erythreae (6.03\%) and Euterpina acutifrons (6.03\%). 
In station 1, the species richness index for zooplankton varied from 3.33 to 7.13 (Figure 3 ). The minimum and maximum values were observed during the months of September 2016 and April 2017 respectively. In station 2 , the species richness index value ranged from 3.64 to 6.29 (Figure 3). The minimum and maximum values were observed during the months of October 2016 and April 2017 respectively.
In station 1, the species diversity index for zooplankton ranged between 0.88 and 1.58 bits / individual (Figure 4). The minimum and maximum values were observed during the months of May and April 2017 respectively. In station 2, the species diversity index ranged from 1.16 to 1.51 bits / individual (Figure 4). The minimum and maximum values were observed during the months of May 2017 and November 2016 respectively.

Table.1 Monthly variation of water quality parameters in Station 1

\begin{tabular}{|l|r|r|r|r|r|r|r|r|r|}
\hline \multicolumn{1}{|c|}{ Parameters } & Sep-16 & Oct & \multicolumn{1}{|c|}{ Nov } & Dec & Jan-17 & Feb & Mar & Apr & May \\
\hline Water temperature $\left.\mathbf{(}^{\mathbf{0}} \mathbf{C}\right)$ & 29.00 & 29.00 & 26.00 & 25.00 & 26.00 & 26.00 & 28.00 & 29.00 & 30.00 \\
\hline pH & 7.69 & 8.09 & 7.93 & 7.88 & 8.16 & 8.00 & 7.90 & 8.14 & 8.23 \\
\hline Salinity $(\mathbf{p p t})$ & 34.00 & 32.00 & 35.00 & 36.00 & 35.00 & 33.00 & 34.00 & 35.00 & 35.00 \\
\hline Dissolved oxygen $(\mathbf{m l} / \mathbf{l})$ & 4.69 & 3.57 & 3.79 & 3.91 & 3.35 & 3.57 & 3.80 & 3.24 & 4.24 \\
\hline Nitrite $(\boldsymbol{\mu M})$ & 0.10 & 0.25 & 0.20 & 0.22 & 0.48 & 0.51 & 0.03 & 0.07 & 0.22 \\
\hline Nitrate $(\boldsymbol{\mu M})$ & 0.03 & 0.01 & 0.01 & 0.01 & 0.01 & 0.01 & 0.01 & 0.01 & 0.02 \\
\hline Phosphate $(\boldsymbol{\mu M})$ & 0.67 & 0.69 & 0.81 & 0.83 & 0.56 & 0.56 & 0.11 & 0.75 & 0.95 \\
\hline Silicate $(\boldsymbol{\mu M})$ & 1.10 & 1.75 & 1.46 & 1.67 & 1.23 & 0.08 & 1.17 & 0.16 & 0.29 \\
\hline $\begin{array}{l}\text { Gross production }(\mathbf{m g} \mathbf{C} \\
\text { /m3/hr) }\end{array}$ & 1.20 & 0.10 & 0.20 & 0.62 & 0.13 & 0.10 & 0.23 & 0.17 & 0.20 \\
\hline Chlorophyll-a $(\mathbf{m g} / \mathbf{m 3})$ & 0.30 & 1.31 & 2.11 & 0.06 & 0.09 & 0.46 & 0.61 & 0.01 & 0.80 \\
\hline
\end{tabular}

Table.2 Monthly variation of water quality parameters in Station 2

\begin{tabular}{|l|r|r|r|r|r|r|r|r|r|}
\hline \multicolumn{1}{|c}{ Parameters } & Sep-16 & Oct & Nov & Dec & Jan-17 & Feb & Mar & Apr & May \\
\hline Water temperature $\left({ }^{\mathbf{0}} \mathbf{C}\right)$ & 29.00 & 30.00 & 27.00 & 26.00 & 26.00 & 27.00 & 27.00 & 29.00 & 30.00 \\
\hline pH & 7.85 & 8.08 & 8.02 & 7.74 & 8.14 & 7.98 & 7.68 & 8.19 & 8.11 \\
\hline Salinity $(\mathbf{p p t})$ & 33.00 & 31.00 & 35.00 & 36.00 & 35.00 & 32.00 & 34.00 & 35.00 & 35.00 \\
\hline Dissolved oxygen $(\mathbf{m l} / \mathbf{l})$ & 3.35 & 3.80 & 4.24 & 4.57 & 4.69 & 4.36 & 3.46 & 3.57 & 3.13 \\
\hline Nitrite $(\boldsymbol{\mu M})$ & 0.08 & 0.28 & 0.26 & 0.24 & 0.35 & 0.63 & 0.13 & 0.39 & 0.13 \\
\hline Nitrate $(\boldsymbol{\mu M I})$ & 0.02 & 0.01 & 0.03 & 0.02 & 0.01 & 0.01 & 0.03 & 0.01 & 0.01 \\
\hline Phosphate $(\boldsymbol{\mu M})$ & 0.84 & 0.85 & 0.90 & 0.82 & 0.23 & 0.44 & 0.16 & 0.62 & 0.59 \\
\hline Silicate $(\boldsymbol{\mu M})$ & 1.09 & 1.36 & 1.26 & 1.24 & 1.17 & 0.60 & 1.14 & 0.50 & 1.26 \\
\hline $\begin{array}{l}\text { Gross production }(\mathbf{m g ~ C} \\
\text { /m3/hr) }\end{array}$ & 0.60 & 0.30 & 0.12 & 0.10 & 0.20 & 0.25 & 0.15 & 0.13 & 0.17 \\
\hline Chlorophyll-a $(\mathbf{m g} / \mathbf{m 3 )}$ & 0.15 & 0.61 & 0.17 & 0.02 & 0.06 & 0.46 & 0.16 & 0.02 & 0.52 \\
\hline
\end{tabular}


Figure.1 Map showing the study area
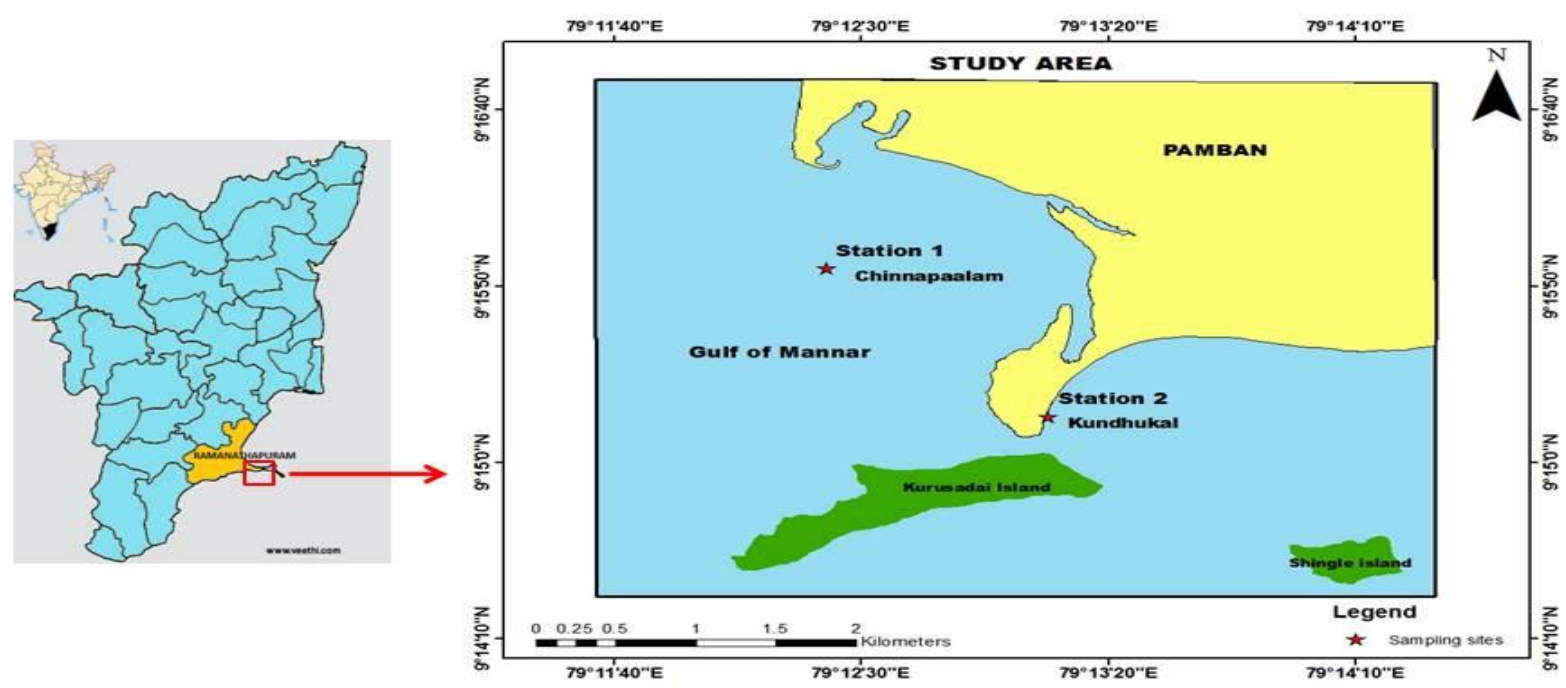

Figure.2 Seasonal variations of zooplankton density in stations 1 and 2

Months

Figure.3 Seasonal variation of species richness (D) of zooplankton in station 1 and 2

Species Richness Index

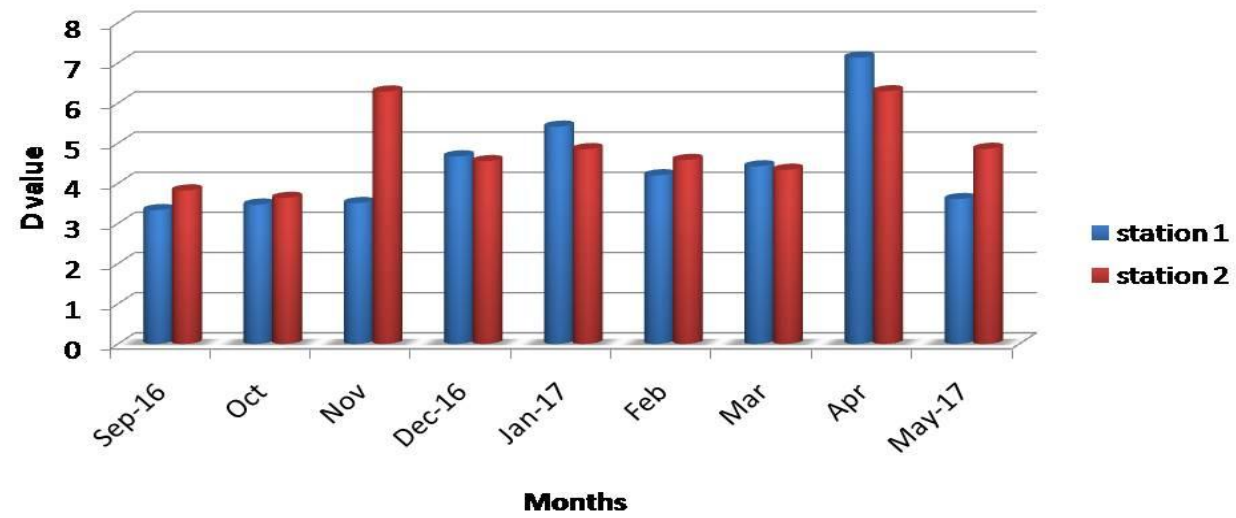


Figure.4 Seasonal variation of species diversity $\left(\mathrm{H}^{\prime}\right)$ of zooplankton in station 1 and 2

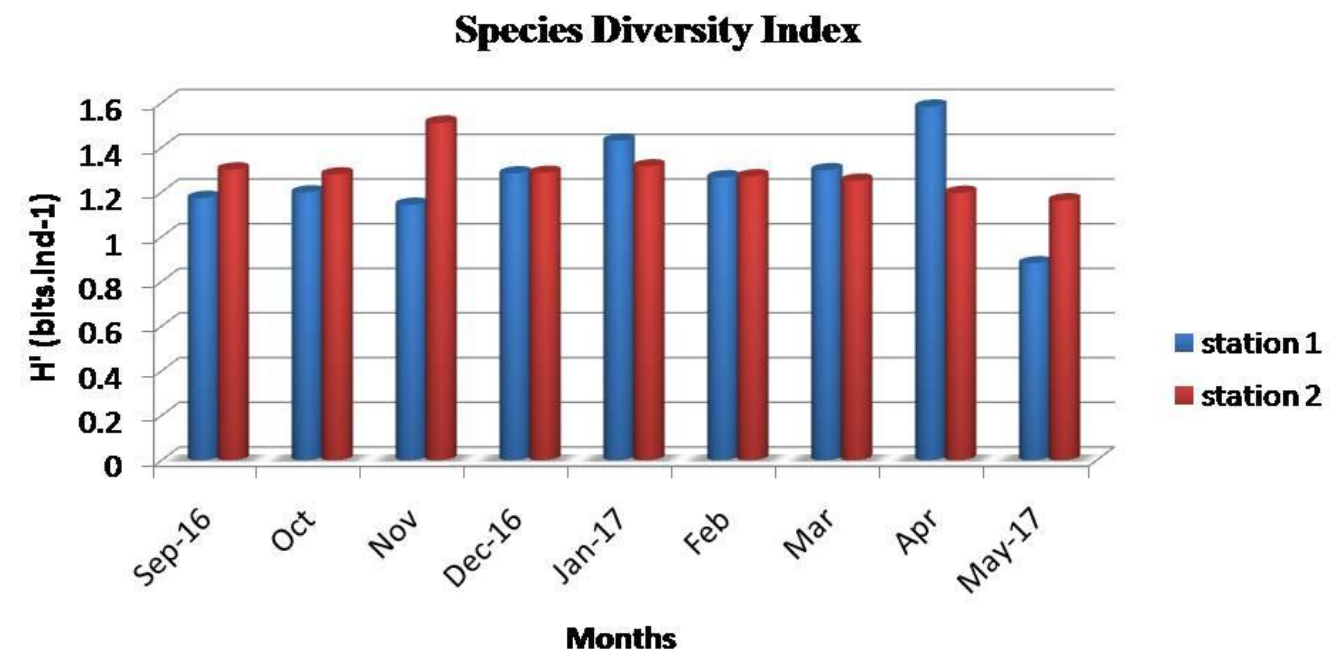

Temperature is one of the most important factors controlling the physiological activities of the animals. In the present study, the surface water temperature variation is found to be uniform in all the three stations with the range of values from 25 to $30^{\circ} \mathrm{C}$. The optimum temperature range required for the growth of seagrass have been reported as 23 $32^{\circ} \mathrm{C}$ (Short et al., 2016) and the observed values were within the range. The $\mathrm{pH}$ values were ranged from 7.68 to 8.23 . Arumugam et al., (2013) have also reported the similar values of $\mathrm{pH}$ with the range of 7.7 to 8.5 in the seagrass meadows of Gulf of Mannar. Salinity acts as a limiting factor in the distribution of living organisms (Anand et al., 2015). The salinity values of the two stations varied between 31 and 36 ppt. Kannapiran et al., (2008) also observed the salinity values ranged between 30.6 and 34.5 ppt in the Gulf of Mannar region. Dissolved oxygen in water is a very important parameter as it serves as an indicator of the physical, chemical and biological parameters of the water body. In the present study, the dissolved oxygen values of the two stations varied between 3.13 and $4.69 \mathrm{ml}^{-\mathrm{l}^{-1}}$. The maximum value of $5.9 \mathrm{ml}^{. \mathrm{l}^{-1}}$ was recorded by Sulochanan et al., (2011) in seagrass ecosystem of Palk Bay. Nutrients are the major factor controlling the plankton growth in aquatic ecosystem. However, the seagrass ecosystem could be affected by persistent higher nutrient levels for longer periods (Sridhar et al., 2008). Nitrogen and phosphorous are the major limiting factors for seagrass growth (Arumugam et al., 2013). Sulochanan et al., (2011) have recorded the maximum level of nitrite as $0.63 \mu \mathrm{M}$ in seagrass beds of Gulf of Mannar. Sridhar et al., (2008) also observed the nitrite values ranged between 0.03 and $2.91 \mu \mathrm{M}$ in the seagrass ecosystem. The values of nitrate ranged from 0 to $0.03 \mu \mathrm{M}$ in both the stations. Anandakumar and Tajuddin (2013) reported the minimum value of $0.2 \mu \mathrm{M}$ in the selected locations of Gulf of Mannar region. The concentration of phosphate in both the stations ranged from 0.11 to $0.95 \mu \mathrm{M}$. This higher concentration can also be spotted in seagrass ecosystem due to the terrestrial run off and release of organic phosphorous from the bottom (Kannapiran et al., 2008). Silicate is not an essential nutrient for seagrasses. However, it is required by the associated organisms especially diatoms. The concentration of silicate in two stations ranged from 0.08 to $1.98 \mu \mathrm{M}$. The values of silicate are found to be higher than other 
nutrients in both the stations and it was also supported by Sridhar et al., (2008) and Anandakumar and Tajuddin (2013). In the present study, the gross productivity ranged from 0.10 to $1.20 \mathrm{mg} \cdot \mathrm{C} \cdot \mathrm{m}^{-3} \cdot \mathrm{h}^{-1}$ in both the stations. The highest value in seagrass ecosystem indicated that it is more productive than the areas without seagrass. Prasath et al., (2011) suggested that stable condition of salinity and other physicochemical parameters could promote the plankton production. Chlorophyll-a values observed during the study period in both the stations varied from 0.01 to $2.11 \mathrm{mg} \cdot \mathrm{m}^{-3}$. The overall maximum value $\left(2.11 \mathrm{mg} . \mathrm{m}^{-3}\right)$ was recorded in the seagrass ecosystem. Similar studies were also conducted by Anand et al., (2015) and Mahesh et al., (2015) and the results corroborates with the present study.

In the present study, a total of 65 species of zooplankton were identified from both the stations. The number of species is more in seagrass ecosystem compared to the other stations. Anandakumar and Tajuddin (2013), Pitchaikani and Lipton (2015), and Jeyaraj et al., (2016) have documented 72, 49 and 114 species of zooplankton respectively in Gulf of Mannar region. Among the zooplankton species, diatoms were found to be the dominant group followed by meroplanktonic forms. Many researchers (Fernandes and Ramaiah, 2009; Kumar and Perumal, 2011; Prasath et al., 2011 and Mahesh et al., 2015) documented copepods as the dominant group in the coastal waters of India. Similarly, Calanoid copepods and larvae of crabs were registered as the dominant species in Gulf of Mannar by Pitchaikani and Lipton (2015).

The comparison of zooplankton density between seagrass ecosystem and the control station revealed that the former is more than the later. Jeyaraj et al., (2016) observed the maximum density of 11733 nos. $/ \mathrm{m}^{3}$ in the Gulf of Mannar region. The species richness value of zooplankton in all both the stations varied from 2.97 to 7.13 . The maximum species richness was recorded in seagrass ecosystem followed by control station. The species diversity value $\left(\mathrm{H}^{\prime}\right)$ for zooplankton in both the stations varied from 0.88 to 1.58 bits / individual. Prasath et al., (2011) reported the range of $\mathrm{H}^{\prime}$ value from 0 to 2.88 bits / individual along the east coast of India. Pitchaikani and Lipton (2015) recorded the species diversity in the range of 3.29 to 3.77 bits / individual in Tiruchendur coast of Gulf of Mannar region.

From the present investigation, it can be concluded that the seagrass ecosystem harbours high diversity of zooplankton as that of the open waters providing suitable nursery grounds for the juveniles of fin and shellfishes.

\section{Acknowledgement}

The authors are thankful to The Dean, Fisheries College and Research Institute, Tamil Nadu Dr. J. Jayalalithaa Fisheries University, Thoothukudi.

\section{References}

Anand, D.J.B., Kala, S.M.J., Kumar, P.V. 2015. Monthly variations of water quality along south east coast of India. International Journal of Geology, Agriculture and Environmental Sciences, 3(3), 10-15.

Anandakumar, N., Thajuddin, N., 2013. Physico-chemical properties, seasonal variations in species composition and abundance of micro zooplankton in the Gulf of Mannar, India. Indian $J$. GeoMarine Sci., 42(3), 383-389.

Arumugam, R., Kannan, R.R.R., Saravanan, K.R., Thangaradjou, T., Anantharaman, P., 2013. Hydrographic and sediment characteristics of seagrass meadows of 
the Gulf of Mannar Marine Biosphere Reserve, South India. Environ. Monit. Assess. 185(10), 8411-8427.

Fernandes, V., Ramaiah, N., 2009. Mesozooplankton community in the Bay of Bengal (India): spatial variability during the summer monsoon. Aquat Ecol. 43(4), 951-963.

Gleason, H.A., 1922. On the relation between species and area. Ecology, 3,156-162.

Gopakumar, G., Sulochanan, B., Venkatesan, V., 2009. Bloom of Noctiluca scintillans (Macartney) in Gulf of Mannar, southeast coast of India. $J$. Mar. Biol. Ass. India. 51(1), 75-80.

Jeyaraj, N., Ravikumar, S., Rajthilak, C., Kumar, S.P., Santhanam, P., 2016. Abundance and Diversity of Zooplankton along the Gulf of Mannar Region, Southeast Coast of India. International Journal of Marine Science, 6(28),1-9.

Jyothibabu, R., Mohan, A.P., Jagadeesan, L., Anjusha, A., Muraleedharan, K.R., Lallu, K.R., Kiran, K., Ullas, N., 2013. Ecology and trophic preference of picoplankton and nanoplankton in the Gulf of Mannar and the Palk Bay, southeast coast of India. J Mar. Syst. 111, 29-44.

Kannapiran, E., Kannan, L., Purushothaman, A., Thangarajdou, T., 2008. Physicochemical and microbial characteristics of the coral reef environment of the Gulf of Mannar marine biosphere reserve, India. J. Env. Biol. 29(2), 215222.

Kasturirangan, L.R., 1963. A key for the identification of the more common planktonic copepod of Indian coastal waters. Indian National Committee on Oceanic Research Publication No.2, CSIR. New Delhi, 87pp.

Kumar, C.S., Perumal, P., 2011. Hydrobiological Investigations in Ayyampattinam Coast (Southeast Coast of India) with Special Reference to Zooplankton. Asian J Biol. Sci., 4,2534.

Mahesh, R., Saravanakumar, A., Thangaradjou, T., Solanki, H.U., 2015. Influence of environmental parameters in phyto and zooplankton assemblages in the Tamil Nadu coast, south-western Bay of Bengal. J. Coast. Sci. 2(2), 1233.

Pitchaikani, J.S., Lipton, A.P., 2015. Seasonal variation of zooplankton and pelagic fish catch in the fishing grounds off Tiruchendur coast, Gulf of Mannar, India. Ecohydrol. Hydrobiol. 15(2), 89100.

Prasath, B.B., Nandakumar, R., Santhanam, P., Perumal, P., Ananth, S., Kumar, S.D., Devi, A.S., Chinnaraja, V., Kuyili, P., Ananthi, P., 2011. An investigation on the hydrography and plankton ecology of Coromandel Coast, southeast coast of India. In: Santhanam, P., P. Perumal, (Eds.), Marine biodiversity: Present status and prospects, Narendra publishing house, Delhi, pp. 75-89.

Santhanam, R., Srinivasan, A., 1994. A manual of marine zooplankton. Oxford and IBH Publishing Co., New Delhi, $160 \mathrm{pp}$.

Shannon C.E., Weaner W., 1949. The mathematical theory of communication (University of Ilinois press, Urbana), $117 \mathrm{p}$.

Short, F.T., Kosten, S., Morgan, P.A., Malone, S., Moore, G.E., 2016. Impacts of climate change on submerged and emergent wetland plants. Aquat. Bot. 135, 3-17.

Sridhar, R., Thangaradjou, T., Kannan, L., 2008. Comparative investigation on physico-chemical properties of the coral reef and seagrass ecosystems of the Palk Bay. Indian J. Mar. Sci. 37, 207-213.

Strickland, J.D.H., Parsons, T.R., 1972. A practical handbook of seawater analysis. 
Bulletin, Fisheries Research Board of Canada No.167, 310 pp.

Sulochanan, B., Kumaraguru, A.K. and Korabu, L.S., 2011. Hydrological conditions in seagrass beds in Palk Bay and Gulf of Mannar, southeast coast of India. J. Mar. Biol. Ass. India. 53(1), pp. 108-115.

\section{How to cite this article:}

Deepika, S., A. Srinivasan, P. Padmavathy and Jawahar, P. 2019. Diversity of Zooplankton in Seagrass Ecosystem of Mandapam Coast in Gulf of Mannar. Int.J.Curr.Microbiol.App.Sci. 8(07): 2034-2042. doi: https://doi.org/10.20546/ijcmas.2019.807.244 